\title{
Ecological and economic situation and methods of modern agricultural land-use
}

\author{
Krasnolutskyi O. ${ }^{1}$, Shevchenko 0. ${ }^{2}$
}

${ }^{1}$ State service of Ukraine on geodesy, cartography and cadastre, Narodnogo Opolchennia Str., 3, Kyiv, 03151, Ukraine, ${ }^{2}$ National university of bioresources and natural management of Ukraine, Vasylkivska Str., 17, Kyiv, 03040, Ukraine; e-mail: ${ }^{1}$ krasnolutski@land.gov.ua, ${ }^{2}$ shevchenko_ov90 @ukr.net.

The purpose. To analyze modern state and methods of agricultural land-use, to assess efficiency of land-and-resource potential of Ukraine. Methods. Analysis, synthesis, systematization, calculation and generalization of absolute and comparative figures, abstract-logical, etc. Results. Modern structure of land fund of Ukraine and its dynamics is used. Efficiency factors of use and reconstitution of lands of agricultural assignment in modern conditions are specified. Efficiency of land-and-resource potential is analyzed. Conclusions. Directions are justified martempering ecological and economic state of modern agricultural land-use.

Key words: agricultural land-use, economic efficiency, degradation of lands, fertility of soils.

Introduction (problem statement). As known, land resources are characterized by specific features that greatly affect the effectiveness of its use. However, the critical level of pollution, high acidity, wind and water erosion make it impossible to use and reproduce land resources efficiently. First of all, it concerns agricultural land, because the productivity and quality of agricultural products depend on their fertility.

Modern development and efficiency of agricultural production do not correspond to the potential possibilities of its main resource, land, as a result of inconsistency of socio-industrial relations, in particular land, with the needs of sustainable development of agrarian production, which involves the mutual harmonization of environmental, economic and social factors. Therefore, it can be argued that the revival of our country should begin with the reproduction of agricultural land resources, ensuring a balance between the solution of socio-economic and environmental problems of land conservation. Therefore, the problem of efficient and rational land-use should be at the center of attention of both the state and landowners, and land users themselves.

Analysis of recent research and publications. The use of land-resource potential in agriculture is investigated by such local scientists as D.I. Bambindra, I.K. Bystryakov, A.S. Danilenko, D.S. Dobriak, O.P. Kanash, A.H. Martin, L.Y. Novakovsky, M.H. Stupen, A.M. Tretyak, M.A. Khvesik, M.K. Shykula and many others. However, many aspects of the problem, such as rational use, efficiency improvement, reproduction and land protection remain insufficiently highlighted and require further elaboration.

The purpose of the research is to analyze the current state and methods of agricultural land use, to evaluate the efficiency of land and resource use in Ukraine.

Research methods. The following main methods were used to achieve the purpose of the research: monographic analysis, when processing scientific publications on issues of ecologically safe use of agricultural lands; comparative and statistical analysis in studying the dynamics of the structure of the land fund of Ukraine by the main types of land and economic activity; economic analysis and calculation of relative indicators for carrying out an estimation of economic efficiency of use of agricultural lands; abstractlogical method with theoretical generalizations and the formation of conclusions, etc.

The results of the research. The basis of agricultural production are land resources, which are the main means of production in this area of the economy. However, the state and level of land use were and still remain one of the main obstacles to the steady development of the agrarian sector of Ukraine.

Ukraine is the largest country in Europe (excluding the European part of the Russian Federation), the land fund of the country is 60,35 million hectares [1], which occupies $5,7 \%$ of the territory of Europe and 
$0,5 \%$ of the globe. In addition, among the European countries in terms of agricultural land supply, Ukraine ranks third only in Belarus ( 0,90 hectares per inhabitant) and Greece (0,84 hectares), and is also the eighth highest in the world with arable land yielding to Australia (2,15 hectares of arable land per capita), Kazakhstan (1,48 hectares), Canada (1,34 hectares), St. Helena (1,00ha), Russian Federation $(0,85$ hectares), Argentina (0,77 hectares) [2, 3].

Thus, the area of agricultural lands per inhabitant in Ukraine is 0,81 hectares, while the arable land per one inhabitant is 0,71 hectares [3]. However, in Ukraine, in order to provide the population with food and obtain raw materials for industry, land resources are not always used effectively, which significantly impedes the development of the Ukrainian economy.

The composition and structure of land are one of the determining factors of the efficiency of land use in Ukraine. Thus, according to the data of the State Geodesy Cadastre of Ukraine, agricultural land occupies 42,7 million hectares (or $70,8 \%$ ) of the total area of the country as of January 1, 2016; forests and other forested areas $-10,6$ million hectares $(17,6 \%)$; built-up land -2.5 million hectares $(4,2 \%)$; open wetlands almost 1 million hectares $(1,7 \%)$; open earths without plant cover or with insignificant vegetation (stony places, sands, ravines) and dry open lands with a special vegetation cover - 1,0 million ha $(1,7 \%)$; under water $-2,4$ million hectares $(4,0 \%)$.

At the same time, there have been some changes in 2003-2016, as the dynamics of the distribution of land fund in Ukraine for the main types of land (Figure 1) shows. In particular, the area of agricultural land has decreased by 331,3 thousand hectares, as well as the area of open lands decreased by 22,9 thousand hectares. At the same time, the area of forests and forestland territories increased by 219,6 thousand hectares, and more land was built on 66,9 thousand hectares. Also, the area of open waterlogged lands and territories under water objects increased by 35,1 thousand hectares and 2,9 thousand hectares, respectively.

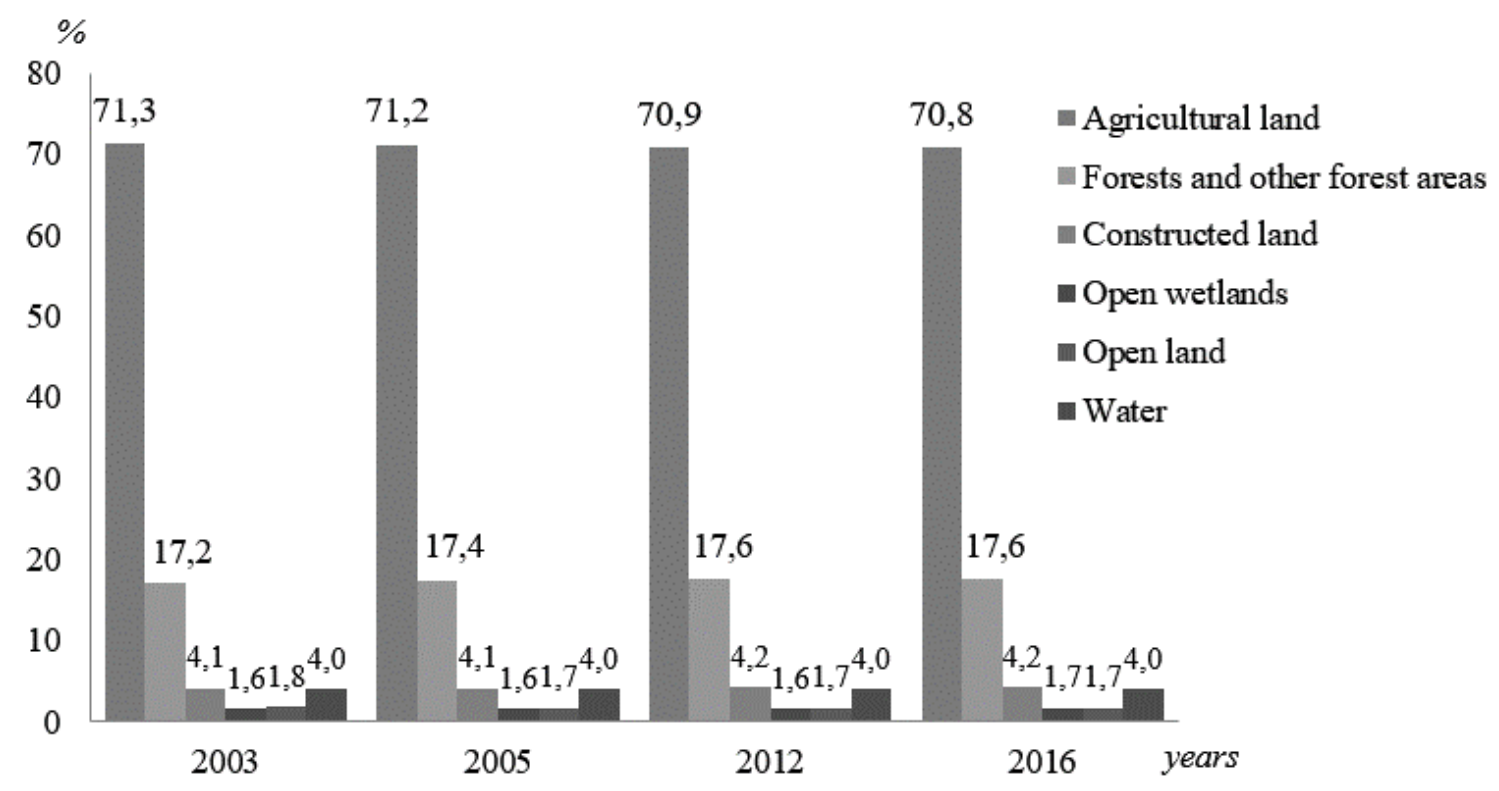

Figure 1. The dynamics of the land fund of Ukraine from 2005 to 2016 [1]

From the above data, it can be argued that agricultural lands are located more than $2 / 3$ of Ukraine, which indicates a high level of agricultural development of the territory. The highest agricultural development is observed in the Kirovograd region, its share is $84,6 \%$, also in Zaporozhye $-84,5 \%$, Mykolaiv region - 83,6\%, and Dnipropetrovsk region $-80,9 \%$. The lowest level in the Zakarpattia region is $36,8 \%$, also in IvanoFrankivsk region $-46,3 \%$, Rivne region $-47,8 \%$.

An important part of the analysis of the state of agricultural land use is the study of the existing structure of the most valuable land in Ukraine - agricultural land. Thus, as of January 1, 2016, the largest share is the arable land, which occupy an area of 32541,3 thousand hectares, or $78,4 \%$ of the total area of agricultural land, indicating a high level of cultivating. At the same time, the level of cultivating agricultural land ranges from $90,3 \%$ (Kherson region) to $44,4 \%$ (Transcarpathian region). As for other types of agricultural land, 
2406.4 thousand hectares are occupied by hayfields, 5434,1 thousand hectares of pasture, 892.4 thousand hectares of perennial plantations, 233,7 thousand hectares of abandoned field.

Assessing the structure of land resources for their economic use as of January 1, 2016, it should be noted that Ukraine has formed a rather high level of development of living space, since about $65 \%$ of its territory is involved in economic use (Table 1 ), where only 21,3 million hectares $(35,3 \%)$ ecologically stabilizing lands. In addition, this assessment of the distribution of land resources of Ukraine for their economic use shows that the largest share belongs to agriculture $-69,8 \%$, forestry $-14,7 \%$, as well as other non-utilization of land $-5,4 \%$ and protection of the environment $-4,8 \%$.

However, the assessment of the allocation of land resources for their economic use does not provide sufficient economic and environmental clarity and reasonableness. To improve this, an analysis of the assessment of the ecological stability of the territory and anthropogenic pressure on land resources is necessary.

The assessment of the ecological stability of land use within the regions of Ukraine by calculating the ecological stability coefficient shows that the ecological stability of land use in the territory of Ukraine is stable unstable (Kec.st. = 0,40), and in such areas as Dnipropetrovsk, Donetsk, Zaporozhye , Kirovograd, Odessa, Mykolaiv, Poltava, the state of land use is even environmentally unstable. In addition, only one area is ecologically stable (Zakarpattia region). As to the coefficient of anthropogenic loading (Q.), which characterizes the degree of influence of human activities on the state of the environment, including land resources, the country as a whole, it is 3 points and is characterized by an average level of occupancy [4].

Thus, our state does not meet the ecological and economic requirements for the general state of land use, which is close to the dangerous limit that could lead to irreparable ecological processes.

In order to objectively assess the state of agricultural land use, the study of the economic efficiency of agricultural land use in Ukraine is a prerequisite.

Table 1. Estimation of the structure of land resources of Ukraine for their economic use as of 01.01.2016 *

\begin{tabular}{|c|c|c|c|c|c|c|}
\hline \multirow{3}{*}{ № } & \multirow{3}{*}{$\begin{array}{l}\text { Types of economic } \\
\text { land use }\end{array}$} & \multicolumn{5}{|c|}{ Total area } \\
\hline & & \multirow{2}{*}{\begin{tabular}{|c|} 
total, \\
thousand \\
hectares
\end{tabular}} & \multirow{2}{*}{$\begin{array}{c}\% \text { to the } \\
\text { total } \\
\text { territory }\end{array}$} & \multicolumn{3}{|c|}{ including thousand hectares } \\
\hline & & & & $\begin{array}{l}\text { plowing } \\
\text { land }\end{array}$ & $\begin{array}{c}\text { under } \\
\text { construction }\end{array}$ & $\begin{array}{l}\text { under ecological } \\
\text { stabilizing lands }\end{array}$ \\
\hline & Agriculture & 42131,0 & 69,8 & 32173,4 & 1162,0 & 8795,6 \\
\hline & Residential and other buildings & 987,1 & 1,6 & 59,8 & 576,0 & 351,3 \\
\hline & including waste disposal & 16,5 & 0,0 & - & - & - \\
\hline 3. & Forestry & 8868,4 & 14,7 & 1079,1 & 791,7 & 6997,6 \\
\hline & Water management & 243,9 & 0,4 & 1,6 & 28,8 & 213,5 \\
\hline & Industry and others & 1653,7 & 2,7 & 223,2 & 968,0 & 462,5 \\
\hline \multicolumn{2}{|r|}{$\begin{array}{c}\text { including for the development of minerals, } \\
\text { open-cuts }\end{array}$} & 157,1 & 0,3 & - & - & - \\
\hline 6. & Environmental protection & 2909,8 & 4,8 & 1,0 & 1,5 & 2907,3 \\
\hline 7. & Health care maintaining & 160,9 & 0,3 & 3,2 & 47,4 & 110,3 \\
\hline 8. & Culture, spirituality, etc. & 170,8 & 0,3 & 42,2 & 69,4 & 59,2 \\
\hline 9. & Other unused land & 3229,3 & 5,4 & 1044,1 & 777,2 & 1408,0 \\
\hline \multirow{2}{*}{\multicolumn{2}{|c|}{ in $\%$ of the total area }} & 60354,9 & 100,0 & 34627,6 & 4422,0 & 21305,3 \\
\hline & & & & 57,4 & 7,3 & 353 \\
\hline
\end{tabular}

${ }^{*}$ Calculated and compiled by the authors according to the data [1,5].

In the structure of Ukraine's crops area, the state of 2016 is dominated by grain and leguminous crops that make up $53,4 \%$, while the share of technical crops is $32,8 \%$, on feed crops $-7,1 \%$, and on other crops (potatoes, vegetable crops and melons food) $-6,8 \%$. In the structure of the crops area of the main crops, a significant transformation is observed by reducing the share of fodder crops by more than 5 times, from $37,0 \%$ in 1990 to almost $9 \%$ in 2016. This situation is explained by a decrease in livestock production, and as a result, a decrease in the level of organic fertilizer application. At the same time, the increase in the share of industrial crops almost 3 times, from $11,6 \%$ in 1990 to $32,8 \%$ in 2016 , is due to an increase in the sown area of highly profitable crops (sunflower, soya, etc.) (Table 2). 
An assessment of the economic efficiency of agricultural land use, in terms of production of basic agricultural products per 100 hectares of a certain type of agricultural land, is shown in Figure 3-4.

Table 2. The structure of sown areas of the main agricultural crops of Ukraine for the years 19902016*

\begin{tabular}{|c|c|c|c|c|c|c|c|}
\hline \multirow{2}{*}{ Indexes } & \multicolumn{5}{|c|}{ Years } & \multicolumn{2}{|c|}{, \pm 2016 to: } \\
\hline & 1990 & 2000 & 2010 & 2013 & 2016 & 1990 & 2010 \\
\hline 1. Total land, million hectares & 60,35 & 60,35 & 60,35 & 60,35 & 60,35 & 100 & 100 \\
\hline 2. Total agricultural land, million hectares & 42,03 & 41,83 & 41,56 & 41,53 & 41,51 & $-0,52$ & $-0,05$ \\
\hline of them arable land & 33,41 & 32,56 & 32,48 & 32,52 & 32,54 & $-0,87$ & $+0,06$ \\
\hline $\begin{array}{l}\text { 3. Sown area of agricultural crops, million } \\
\text { hectares }\end{array}$ & 32,41 & 27,17 & 26,95 & 28,33 & 27,02 & $-5,39$ & $+0,07$ \\
\hline including: grain and leguminous crops & 14,58 & 13,65 & 15,09 & 16,21 & 14,40 & $-0,18$ & $-0,69$ \\
\hline technical crops & 3,75 & 4,19 & 7,30 & 7,87 & 8,85 & $+5,1$ & $+1,55$ \\
\hline forage crops & 12,00 & 7,06 & 2,60 & 2,29 & 1,93 & $-10,07$ & $-0,67$ \\
\hline other crops & 3,08 & 2,28 & 1,97 & 1,96 & 1,84 & $-1,24$ & $-0,13$ \\
\hline 4. Level of & 79,5 & 77,8 & 78,1 & 78,3 & 78,4 & $-1,1$ & $+0,3$ \\
\hline 5. Percentage of sown area in arable land, $\%$ & 97,0 & 83,4 & 83,0 & 87,12 & 83,04 & $-13,96$ & $+0,04$ \\
\hline & ure of $s$ & own ar & & & & & \\
\hline grain and leguminous crops & 45,0 & 50,2 & 56,0 & 57,2 & 53,3 & $+8,3$ & $-2,7$ \\
\hline technical crops & 11,6 & 15,4 & 27,1 & 27,8 & 32,8 & $+21,2$ & $+5,7$ \\
\hline forage crops & 37,0 & 26,0 & 9,6 & 8,1 & 7,1 & $-29,9$ & $-2,5$ \\
\hline other crops & 6,4 & 8,4 & 7,3 & 6,9 & 6,8 & $+0,4$ & $-0,5$ \\
\hline
\end{tabular}

${ }^{*}$ Calculated and compiled by the authors according to the data $[1,4]$.

If we analyze the statistical data from 1990 (see Figure 2), it can be argued that from 1990 to 2000, the volume of production of almost all types of crop production per 100 hectares of arable land and perennial plantations (for fruit and berry crops) substantially decreases. However, since 2000, the volume of crop production has grown substantially, in particular, almost 4 times the production of sunflower, 3 times of grain and leguminous crops, and 1.6 times - potatoes and vegetables. The exception is a significant decrease in the production of sugar beet.

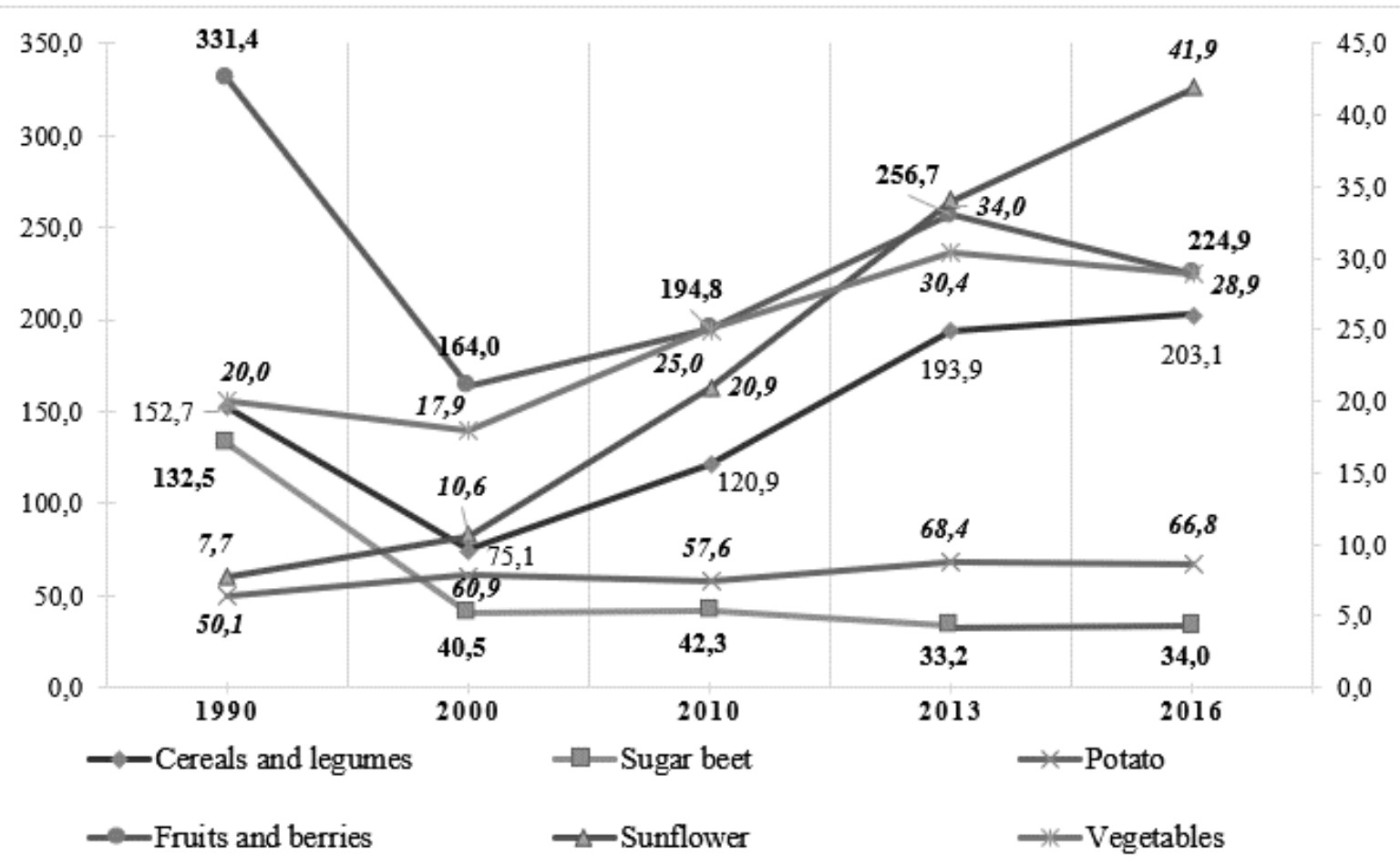

Figure 2. Output of crop production per 100 hectares of arable land and perennial plantations (for fruit and berry crops) in Ukraine for 1990-2016, tons [5] 
As a result of the decline in the livestock sector in Ukraine, the dynamics of livestock production shows (see Figure 3) that in the last 28 years, since 1990, there has been a steady decline in meat of all kinds of animals and milk - 2 times, wool - more than 10 times While in European countries the volume of livestock production is much higher. For example, in France, where the area of agricultural land is 30.3 million hectares, 83.5 tons of milk and 18.8 tons of meat [5] per 100 hectares are received, which is 3 times more than in Ukraine.

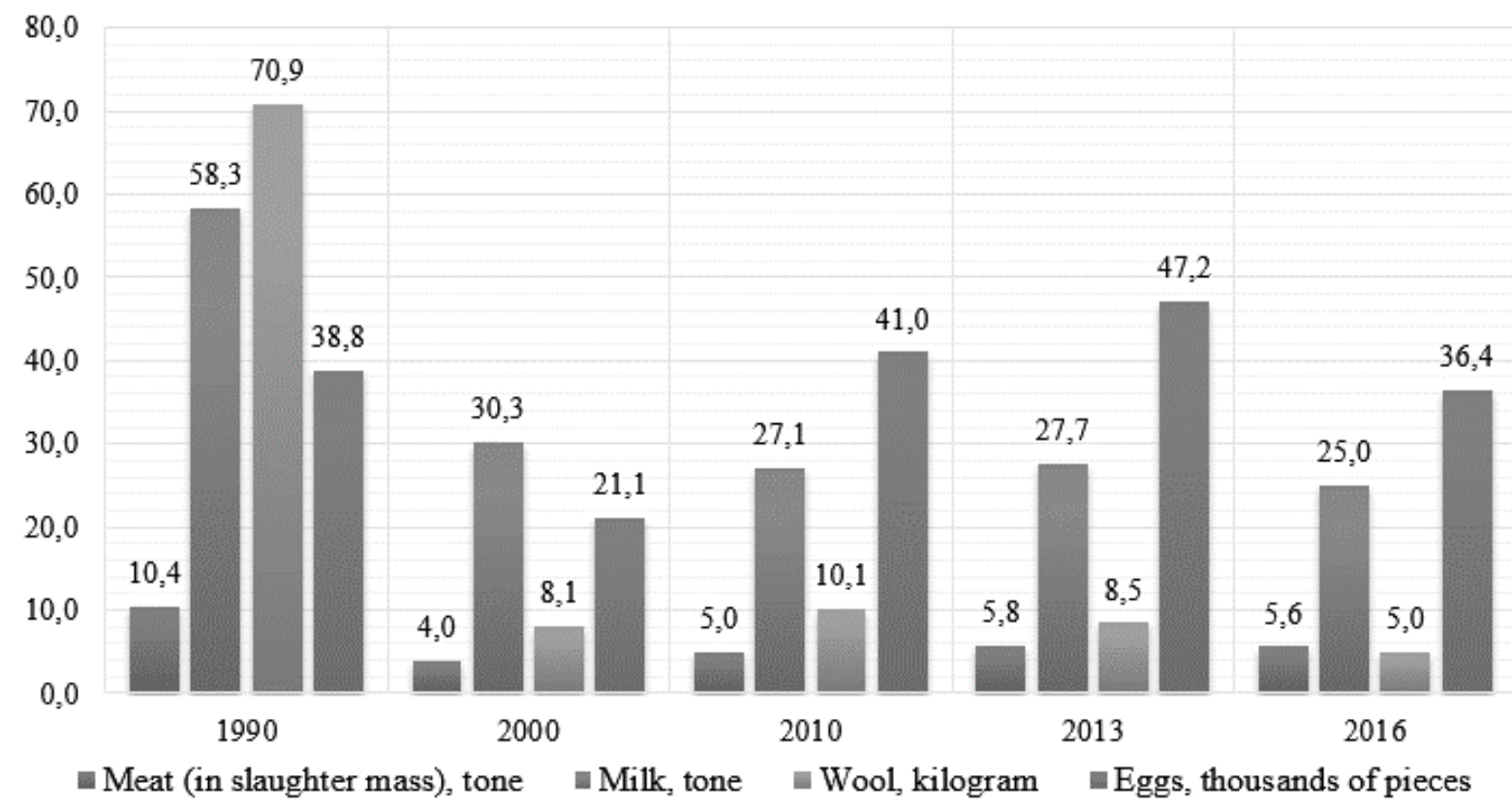

Figure 3. Output of livestock products per 100 hectares agricultural land, tons [5]

Consequently, while assessing the above, it can be argued that the production of basic agricultural products per unit of land is unsatisfactory, despite the fact that the productivity of the main crops in Ukraine in the past 28 years has increased by an average of 1.5-2 times (Fig. 4). However, such indicators are significantly lower in relation to other countries in the world, in which the structural composition and quality of soil is significantly inferior. Thus, the yield of grain and leguminous crops in the UK, France, Germany is 64$68 \mathrm{c} / \mathrm{ha}$, the USA - 67,5 c/ha, in Ukraine - 46,1 c/ha; sugar beet in France - 947,2 centners per hectare, Germany - 628,0 centners per hectare, and the USA - 532,7 centners per hectare, the average in the world - 536,7 centners per hectare, while the yield of sugar beet in Ukraine is 481,5 c/ha [5].

The above results demonstrate non-compliance with technological and ecological requirements of agriculture or, in general, the absence of its culture. At present in Ukraine there is a critical situation with the protection of land. Progressing degradation of soils, their erosion and man-made pollution. Water and wind erosion exposed third of the total area of agricultural land. Excessive agricultural development and cultivation of the territory is one of the main factors that destabilize the ecological situation in our country. 


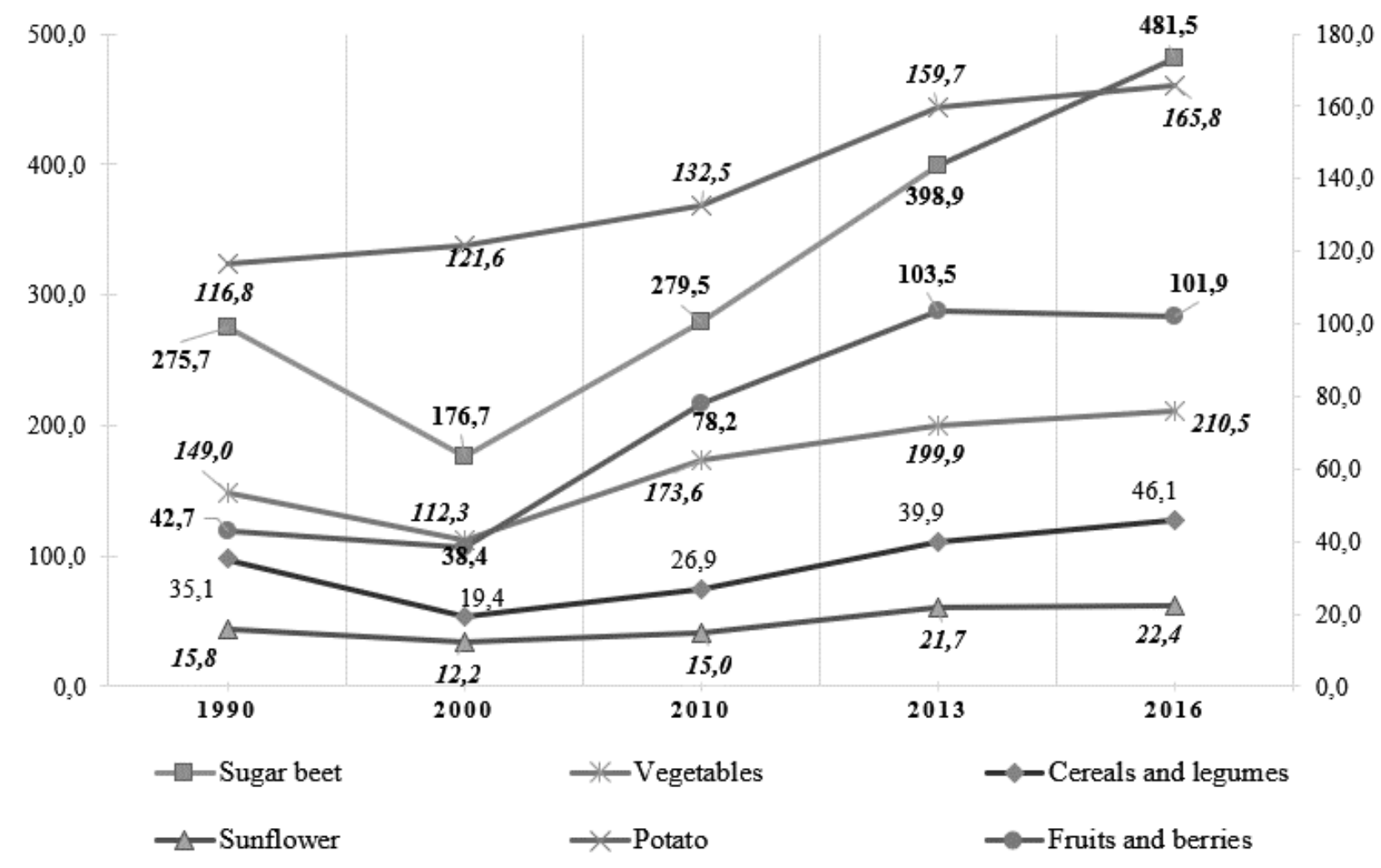

Figure 4. Productivity of main crops in Ukraine for 1990-2016, c/ha [5]

The tendency to decrease humus content in the soil continues due to the reduction of organic and mineral fertilizers, a significant reduction in the area of leguminous crops and perennial grasses, etc. Particularly unfortunate is the fact that today not only tenants are occupied by private land, but also state and communal enterprises and institutions on state-owned land. Recently, a common phenomenon of neglect of crop rotation and cultivation of crops with gross violation of scientifically grounded norms of their alternation or even unchanged crops became widespread. High level of cultivation of land, expansion of crops of energyintensive crops (sunflower, rape, etc.), as well as inadequate care of existing ones and the refusal to introduce new soil protection measures led to the rapid development of erosion processes. The vast majority of land plots are used for commodity agricultural production under lease conditions without any scientifically substantiated rotation of crops [7, 8].

In order to preserve and reproduce the soil fertility, protect them from water and wind erosion, devastating consequences of floods and flooding, as well as increase their productivity, obligatory financing of state and regional land protection programs is required.

The tendency of deterioration of land resources requires subordination of land relations with the main goal to ensure the comprehensive protection of this basic national wealth of Ukraine. This should be the relevant programs for the development of land relations and the use and protection of land. Such programs should be based on a system of legal and regulatory documents that regulate the organizational and economic aspects of the development of land relations, in particular their land management mechanism. Land relations are intended to help overcome existing disadvantages of management, solving environmental and social problems $[9,10]$.

\section{Conclusions}

In general, assessing the current state of land resources we can conclude that the main problem of the land fund of Ukraine is its inefficient use, especially in modern agricultural land use.

In order to avoid this, first of all it is necessary: to set up effective monitoring of land; to optimise the structure of the land fund by converting low-productive and environmentally unstable lands; to reduce and make the most affordable services for ecological and agro-chemical soil surveying, since agricultural producers mostly do not adhere to scientifically grounded crop rotation and soil protection measures, which leads to a decrease in soil fertility; to formulate proper and effective control over the observance of land 
legislation in the area of protection and rational use of land that would ensure the ecological safety of agrarian land use, which is the key to improving the ecological, economic and social indicators of agricultural development in Ukraine.

\section{Bibliography}

1. Forma derzhavnoyi statystychnoyi zvitnosti 6-zem «Zvit pro nayavnist' zemel' ta rozpodil yikh za vlasnykamy zemli, zemlekorystuvachamy, uhiddyamy ta vydamy ekonomichnoyi diyal'nosti» (richna) - Kyiv: Derzhavna sluzhba Ukrayiny z pytan' heodeziyi, kartohrafiyi ta kadastru. - 2017. - 28 s. [In Ukrainian].

2. Kulinich O.M. (2012). Hlobal'ni aspekty dostupnosti zemel'nykh resursiv u konteksti prodovol'choyi bezpeky. Stratehiya rozvytku Ukrayiny. Ekonomika, sotsiolohiya, pravo. № 1. S. 135-141. [In Ukrainian].

3. Solov"yanenko N. (2012). Vykorystannya zemel'nykh resursiv Ukrayiny na suchasnomu etapi rozvytku produktyvnykh syl. Zemlevporyadnyy visnyk. № 7. S. 41-44. [In Ukrainian].

4. Natsional'na dopovid' pro stan navkolyshn'oho pryrodnoho seredovyshcha v Ukrayini u 2015 rotsi. Kyiv: Ministerstvo ekolohiyi ta pryrodnykh resursiv Ukrayiny, FOP Hrin' D.S. - 2017. - 308 s. [In Ukrainian].

5. Sil's'ke hospodarstvo Ukrayiny: statystychnyy zbirnyk za 2016 rik. - Kyiv: Derzhavna sluzhba statystyky Ukrayiny, Derzhanalitinform. 2017. 246 s. [In Ukrainian].

6. Kravchenko O.M. (2014). Efektyvnist' zemlekorystuvannya v sil's'komu hospodarstvi Ukrayiny. Visnyk Kharkivs'koho natsional'noho tekhnichnoho universytetu sil's'koho hospodarstva imeni Petra Vasylenka. Vyp. 149. S. 186-195. [In Ukrainian].

7. Zinchenko T.YE. (2011). Suchasnyy stan vykorystannya zemel'nykh resursiv ahlomeratsiy. Naukovyy visnyk NLTU Ukrayiny. Vyp. 21.12. S. 115-122. [In Ukrainian].

8. Thenail C., Joannon A., Capitaine M. et al. (2009). The contribution of crop-rotation organization in farms to crop-mosaic patterning at local landscape scales. Agriculture, Ecosystems and Environment. № 131 P. 207-219.

9. Kanash O.P. (2011). Zemel'ni vidnosyny: priorytety, ekolohichni ta ekonomichni aspekty. Zemleustriy ta kadastr. Vyp. 3. S. 23-27. [In Ukrainian].

10. Shevchenko O.V., Martyn A.H. (2016). Ekonomichna efektyvnist' gruntookhoronnykh zakhodiv pry vykorystanni zemel' sil's'kohospodars'koho pryznachennya: monohrafiya. Kyiv: TSP «Komprynt», 332 s. [In Ukrainian]. 